\title{
EVALUASI TERAPI ADJUVAN DAN KEJADIAN RELAPS PADA PASIEN PREMENOPAUSAL EARLY BREAST CANCER DI RSUP DR. SARDJITO YOGYAKARTA
}

\author{
EVALUATION OF ADJUVANT THERAPY AND RELAPSE EVENT ON PATIENT OF \\ PREMENOPAUSAL EARLY BREAST CANCER IN RSUP DR. SARDJITO YOGYAKARTA
}

\author{
Fef Rukminingsih'1, Tri Murti Andayani'1, Fita Rahmawati', Kartika Widayati2 \\ 1) Fakultas Farmasi Universitas Gadjah Mada Yogyakarta \\ 2) RSUP Dr. Sardjito Yogyakarta
}

\begin{abstract}
ABSTRAK
Terapi adjuvan pada pasien early breast cancer (EBC) bertujuan untuk meningkatkan disease free survival, menurunkan risiko relaps dan menurunkan angka kematian. Tetapi pada kenyataannya masih sering dijumpai, pasien EBC yang telah mendapat terapi adjuvan mengalami relaps. Kejadian relaps sering dihubungkan dengan meningkatnya risiko kematian tanpa memperhatikan jenis pengobatan. Tujuan penelitian ini adalah mengetahui angka kejadian relaps pada pasien premenopausal EBC yang telah mendapatkan terapi adjuvan di RSUP dr. Sardjito Yogyakarta. Penelitian ini merupakan penelitian deskriptif observasional dengan desain cross sectional study menggunakan data retrospektif yang diperoleh dari data rekam medik pasien premenopausal EBC di Poliklinik Kanker Terpadu "Tulip" RSUP dr. Sardjito Yogyakarta yang telah mengalami tindakan pembedahan pada tahun 20102013, bersifat hormon responsif dan HER-2 negatif, mendapatkan terapi adjuvan, perempuan dengan umur 18-60 tahun dan riwayat pemeriksaan sampai bulan Desember 2016. Pasien akan di eksklusi bila mempunyai penyakit penyerta. Dari 30 pasien diketahui sebanyak 46,67\% berumur 41-50 tahun, sebanyak 63,33\% menunjukkan ekspresi ER-PR positif, sebanyak 93,34\% merupakan invasive ductal carcinoma (IDC). Semua pasien mendapatkan terapi adjuvan kemoterapi menggunakan regimen kombinasi dan semua pasien mendapatkan terapi endokrin berupa tamoksifen. Relaps terjadi pada 11 pasien $(36,67 \%)$ dan kejadian relaps paling banyak adalah metastasis tulang yaitu pada 8 pasien $(26,67 \%)$.
\end{abstract}

Kata kunci : premenopausal, EBC, adjuvan, relaps

\section{ABSTRACT}

Adjuvant therapy in patients with early breast cancer (EBC) aims to improve disease free survival, decrease the risk of relapse and reduce mortality. But in reality they often encountered, EBC patients who had received adjuvant therapy relapse. The incidence of relapse is often associated with increased risk of death regardless of the type of treatment. The purpose of this study was to determine the incidence of relapse in patients premenopausal EBC who have received adjuvant therapy in RSUP dr. Sardjito Yogyakarta. This study is a descriptive observational with cross sectional design using retrospective data obtained from medical records premenopausal EBC patients at Integrated Cancer Clinic "Tulip" RSUP dr. Sardjito Yogyakarta who have undergone surgery in 2010-2013, are hormone responsive and HER-2 negative, have received adjuvant therapy, women aged 18-60 years and a history of the last inspection in December 2016. Patients were excluded if would have comorbidities. From 30 patients known to as much as $46.67 \%$ aged $41-50$ years, as many as $63.33 \%$ showed positive expression of ER-PR, as much as $93.34 \%$ is the IDC. All patients received adjuvant therapy of chemotherapy using a combination regimen and all patients received endocrine therapy such as tamoxifen. Relapses occurred in 11 patients $(36.67 \%)$ and the most incidence of relapse is bone metastasis in 8 patients $(26.67 \%)$.

Keywords : premenopausal, EBC, adjuvant, relapse

\section{PENDAHULUAN}

Penyakit kanker merupakan salah satu penyebab kematian utama di seluruh dunia. Pada tahun 2012, sekitar 8,2 juta kematian di

\section{Korespondensi}

Fef Rukminingsih

Fakultas Farmasi, Universitas Gadjah Mada

Email : fefrukminingsih@gmail.com
Indonesia disebabkan oleh kanker. Kanker payudara merupakan salah satu jenis kanker terbanyak di Indonesia. Berdasarkan Pathological Based Registration di Indonesia, kanker payudara menempati urutan pertama dengan frekuensi relatif sebesar 18,6\%. Diperkirakan angka kejadiannya di Indonesia adalah 12/100.000 perempuan ${ }^{12}$. 
Early breast cancer (EBC) adalah kanker payudara yang masih dapat dilakukan pembedahan (operable) karena sel kanker belum mengalami metastasis, yang termasuk EBC adalah stadium I, II dan III. EBC bisa terjadi pada pasien yang belum menopause (premenopausal) dan yang sudah menopause (postmenopausal). Pemeriksaan immune histo chemistry (IHC) dilakukan untuk mengetahui keterlibatan hormon (estrogen-progesterone receptor) yang akan menentukan pemberian jenis terapi adjuvan ${ }^{11}$. Sekitar $60-75 \%$ kasus baru kanker payudara yang terjadi pada premenopausal adalah hormon responsif ${ }^{2}$.

Tata laksana terapi premenopausal EBC dengan hormon responsif dan Her-2 negatif adalah pembedahan dan terapi adjuvant. Terapi adjuvan meliputi kemoterapi, radiasi, dan terapi endokrin jangka panjang13,4. Terapi adjuvan pada pasien EBC bertujuan untuk meningkatkan disease free survival, menurunkan risiko relaps dan menurunkan angka kematian. Terapi adjuvan yang maju menyebabkan angka mortalitas menurun tajam, namun kejadian relaps masih cukup sering terjadi ${ }^{14}$. Kejadian relaps sering dihubungkan dengan meningkatnya risiko kematian tanpa memperhatikan jenis pengobatan ${ }^{8}$. Tujuan penelitian ini adalah mengetahui angka kejadian relaps pada pasien premenopausal EBC yang telah mendapatkan terapi adjuvan di RSUP dr. Sardjito Yogyakarta.

\section{METODE}

Penelitian ini merupakan penelitian deskriptif observasional dengan desain cross sectional study menggunakan data retrospektif yang diperoleh dari data rekam medik. Kriteria inklusi dari penelitian ini adalah pasien premenopausal EBC di Poliklinik Kanker Terpadu "Tulip" RSUP dr. Sardjito Yogyakarta yang telah mengalami tindakan pembedahan pada tahun 2010-2013, bersifat hormon responsive dan HER-2 negatif, mendapatkan terapi adjuvan berupa kemoterapi dan terapi endokrin, perempuan dengan usia 18-60 tahun dan riwayat terakhir pemeriksaan di RSUP dr. Sardjito sampai bulan Desember 2016. Pasien akan di eksklusi bila mempunyai penyakit penyerta.

Data yang diperoleh dari rekam medik meliputi regimen kemoterapi, ada tidaknya terapi radiasi, terapi endokrin, ada tidaknya kejadian relaps dan lokasi terjadinya relaps. Pengolahan data dilakukan secara kuantitatif dengan menghitung angka kejadian relaps. Analisis hasil penelitian dilakukan secara deskriptif untuk mengevaluasi terapi adjuvan dan kejadian relaps pada pasien premenopausal.

\section{HASIL DAN PEMBAHASAN}

Berdasarkan penelusuran data dari 325 rekam medik diketahui sebanyak 30 pasien yang memenuhi kriteria inklusi dan eksklusi. Sebanyak 295 pasien tidak memenuhi kriteria inklusi dan eksklusi karena pembedahan dilakukan sebelum tahun 2010 atau sesudah tahun 2013, tidak bersifat hormon responsif dan Her-2 positif, kemoterapi tidak lengkap, berumur $>60$ tahun dan pasien sudah tidak aktif berobat di RSUP dr. Sardjito Yogyakarta. Karakteristik pasien premenopausal EBC dengan hormon responsif dan Her-2 negatif yang mendapatkan tindakan pembedahan tahun 2010-2013 di RSUP dr. Sardjito Yogyakarta dapat dilihat pada tabel I.

Pasien premenopausal EBC dengan hormon responsif dan Her-2 negatif paling banyak berumur 41-50 tahun dengan jumlah pasien sebanyak 14 orang (46,67\%). Hal ini sesuai dengan teori bahwa kejadian puncak kanker payudara terjadi pada umur 40-50 tahun. Penelitian ${ }^{18}$ di RSUP dr. Kariadi Semarang juga menunjukkan hasil yang sama yaitu bahwa kanker payudara paling banyak terjadi pada usia 41-50 tahun. Penelitian ${ }^{10}$ menyatakan bahwa umur merupakan salah satu faktor yang berhubungan dengan risiko kanker payudara.

Berdasarkan hasil pemeriksaan IHC diketahui semua pasien premenopausal EBC dengan hormon responsif dan Her-2 negatif bersifat ER+. Hal ini sesuai dengan hasil penelitian ${ }^{7}$ yang menyatakan bahwa dua 
Tabel I. Karakteristik Pasien Premenopausal EBC Dengan Hormon Responsif dan Her-2 Negatif yang Mendapatkan Tindakan Pembedahan Tahun 2010-2013 di RSUP Dr. Sardjito Yogyakarta.

\begin{tabular}{lcc}
\hline Karakteristik Pasien & Jumlah (orang) & Persentase (\%) \\
\hline & Umur pada saat mastektomi (tahun) & \\
\hline $18-30$ & 1 & 3,33 \\
$31-40$ & 6 & 20,00 \\
$41-50$ & 14 & 46,67 \\
$51-60$ & 9 & 30,00 \\
& Keterlibatan hormon & \\
ER positif - PR positif & 19 & 63,33 \\
ER positif - PR negatif & 11 & 36,67 \\
ER negatif - PR positif & 0 & 0 \\
& Jenis histopatologi & \\
IDC & 28 & 93,34 \\
ILC & 1 & 3,33 \\
IDC dan ILC & 1 & 3,33 \\
Ya & Terapi radiasi & 36,67 \\
Tidak & 11 & 63,33 \\
\hline
\end{tabular}

Keterangan

ER: estrogen receptor; PR: progesterone receptor; IDC: invasive ductal carcinoma; ILC: invasive lobular carcinoma

pertiga wanita penderita BC yang berumur $<50$ tahun mempunyai ekspresi ER positif, sedangkan pada wanita berumur $>50$ tahun sekitar $80 \%$ mempunyai ekspresi ER positif.

Berdasarkan jenis histopatologi, pasien premenopausal EBC dengan hormon responsif dan Her-2 negatif dengan diagnosa Invasive ductal carcinoma (IDC) sebanyak 28 orang (93,34\%). Penelitian Irwan dkk (2015) di RSUP dr. M. Djamil Padang juga menunjukkan bahwa $72,9 \%$ kanker payudara merupakan IDC. Hal ini sesuai dengan teori yang menyatakan bahwa sekitar 8 dari 10 kasus kanker payudara invasive merupakan jenis IDC.

Pasien premenopausal EBC dengan hormon responsif dan Her-2 negatif yang tidak mendapatkan terapi radiasi sebanyak 19 orang (63,33\%). Terapi radiasi diberikan setelah dilakukan tindakan breast conserving therapy (BCT) dan diindikasikan bila di daerah tepi sayatan tidak bebas tumor ${ }^{13}$.

Terapi adjuvan kemoterapi seringkali diberikan segera setelah pembedahan dan menggunakan regimen tertentu tergantung dari kondisi pasien. Kemoterapi bertujuan untuk meningkatkan disease free survival. Pemberian kombinasi kemoterapi lebih efektif dibandingkan dengan kemoterapi tunggal ${ }^{16}$. Regimen kemoterapi lini pertama untuk EBC adalah CAF/ FAC (Cyclophospamide, Doxorubin, 5-Fluorouracil), CEF/FEC (Cyclophospamide, Epirubicin, 5-Fluorouracil), AC (Doxorubin, Cyclophospamide), EC (Epirubicin, cyclo-phospamide). Tetapi pada pasien kanker payudara dengan gangguan jantung (ejection fraction $<60 \%$ ), anthracycline harus diganti dengan regimen lain seperti taxane (Suyatno dan Pasaribu, 2014). Regimen kemoterapi yang digunakan pada pasien premenopausal EBC dengan hormon responsive dan Her-2 negatif yang mendapatkan tindakan pembedahan tahun 2010-2013 di RSUP dr. Sardjito dapat dilihat pada tabel II.

Dari tabel II diketahui bahwa semua regimen kemoterapi yang digunakan adalah kombinasi. Terapi adjuvan kemoterapi semua menggunakan regimen kombinasi. Kombinasi yang banyak digunakan adalah doxorubicin, cyclophosphamide dan 5-fluorouracil yaitu sebanyak 20\% karena merupakan regimen lini 
Tabel II. Regimen Kemoterapi Pasien Premenopausal EBC dengan Hormon Responsif dan Her-2 Negatif yang Mendapatkan Tindakan Pembedahan Tahun 2010-2013 Di RSUP Dr. Sardjito Yogyakarta

\begin{tabular}{cllcc}
\hline No & & Regimen dan Frekuensi Kemoterapi & Jumlah (orang) & Persentase (\%) \\
\hline 1 & FAC & $\begin{array}{l}\text { Doxorubicin, Cyclophosphamide } \\
\text { 5-Fluorouracil }\end{array}$ & 6 & 20,00 \\
2 & AC & Doxorubicin, Cyclophosphamide & 5 & 16,67 \\
3 & TAC & Doxorubicin, Cyclophosphamide, Docetaxel & 4 & 13,33 \\
4 & AC Pacli & Doxorubicin, Cyclophosphamide, Paclitaxel & 4 & 13,34 \\
5 & EC Pacli & Epirubicin, Cyclophosphamide, Paclitaxel & 1 & 3,33 \\
6 & AT & Doxorubicin, Docetaxel & 5 & 16,67 \\
7 & A Pacli & Doxorubicin, Paclitaxel & 1 & 3,33 \\
8 & TC & Docetaxel, Cyclophosphamide & 3 & 10,00 \\
9 & FEC $\rightarrow$ T & Epirubicin, Cyclophosphamide, 5-Fluorouracil, & 1 & 3,33 \\
& & Docetaxel & & \\
\hline
\end{tabular}

Tabel III. Terapi Endokrin Pasien Premenopausal EBC dengan Hormon Responsif dan Her-2 Negatif yang Mendapatkan Tindakan Pembedahan Tahun 2010-2013 Di RSUP Dr. Sardjito Yogyakarta

\begin{tabular}{clcc}
\hline No & \multicolumn{1}{c}{ Terapi endokrin } & Jumlah (orang) & Persentase (\%) \\
\hline 1 & Tamoxifen & 18 & 60,00 \\
2 & Tamoxifen dilanjutkan Exemestane (Aromasin) & 2 & 6,67 \\
3 & Tamoxifen dilanjutkan Anastrozole (Arimidex) & 8 & 26,67 \\
4 & Tamoxifen dilanjutkan Letrozole (Femara) & 2 & 6,66 \\
\hline
\end{tabular}

Tabel IV. Kejadian Relaps Pada Pasien Premenopausal EBC Dengan Hormon Responsif dan Her-2 Negatif yang Mendapatkan Tindakan Pembedahan Tahun 2010-2013 do RSUP Dr. Sardjito Yogyakarta

\begin{tabular}{|c|c|c|c|}
\hline No & Kejadian Relaps & Jumlah (orang) & Persentase (\%) \\
\hline 1 & Tidak & 19 & 63,33 \\
\hline \multirow[t]{6}{*}{2} & Ya & 11 & 36,67 \\
\hline & a. Locoregional & 2 & 6,67 \\
\hline & b. Contralateral & 0 & \\
\hline & c. Distant Metastasis & & \\
\hline & 1. Paru & 1 & 3,33 \\
\hline & 2. Tulang & 8 & 26,67 \\
\hline
\end{tabular}

pertama untuk kanker payudara. Pada pasien EBC dengan gangguan jantung digunakan regimen berbasis taxane.Taxane yang lebih banyak digunakan adalah docetaxel dibandingkan paclitaxel karena docetaxel lebih superior dibandingkan paclitaxel, cellular uptake docetaxel lebih cepat dan mempunyai intracellular retention yang lebih lama ${ }^{3}$.
Terapi adjuvan yang harus diberikan pada pasien EBC dengan hormon responsif adalah terapi endokrin. Pemberian terapi endokrin dapat menurunkan angka kematian, menurunkan risiko relaps dan meningkatkan disease free survival ${ }^{2}$. Terapi endokrin pasien premenopausal EBC dengan hormone responsive dan Her-2 negatif yang 
mendapatkan tindakan pembedahan tahun 2010-2013 di RSUP dr. Sardjito dapat dilihat pada tabel III.

Semua pasien dalam penelitian ini mendapatkan tamoxifen karena tamoxifen merupakan pilihan pertama pada terapi pasien premenopausal EBC dengan hormon responsif. Tetapi sebanyak $40 \%$ pasien mengalami menopause setelah pemberian tamoxifen sehingga dilanjutkan dengan golongan aromatase inhibitor yaitu anastrozole, letrozole atau exemestane ${ }^{2}$.

Clinical Outcome dari terapi kanker payudara adalah disease free survival (DFS), relaps (kekambuhan), atau kematian. Relaps bisa terjadi pada tempat kanker pertama kali ditemukan (locoregional), pada payudara lainnya (contralateral) dan distant metastasis ${ }^{5}$. Kejadian relaps pada pasien premenopausal EBC dengan hormone responsif dan Her-2 negatif yang mendapatkan tindakan pembedahan pada tahun 2010-2013 di RSUP dr. Sardjito Yogyakarta dapat dilihat pada tabel IV.

Sebanyak 11 pasien $(36,67 \%)$ mengalami kejadian relaps meskipun sudah mendapatkan terapi adjuvan kemoterapi dan terapi endokrin. Relaps juga terjadi pada pasien BC yang telah mendapatkan terapi adjuvan kemoterapi dan terapi endokrin pada penelitian ${ }^{1}$ sebesar $7-13 \%$. Kejadian relaps dipengaruhi oleh karakteristik sel kanker, stadium kanker, keterlibatan hormon dan pemberian terapi endokrin ${ }^{1}$.

Sebanyak 2 orang $(6,67 \%)$ mengalami relaps locoregional, 1 orang (3,33\%) mengalami relaps metastasis paru dan 8 orang $(26,67 \%)$ mengalami relaps metastasis tulang. Kejadian relaps metastasis tulang paling banyak, karena terapi adjuvan baik kemoterapi maupun terapi endokrin dapat menurunkan kadar estrogen. Penurunan kadar estrogen akan meningkatkan kejadian osteolisis. Pasien premenopausal EBC yang mengalami peningkatan osteolisis akibat terapi endokrin mempunyai resiko tinggi untuk mengalami metastasis tulang ${ }^{4,6}$.

Pasien premenopausal EBC dengan hormon responsif mempunyai peningkatan resiko metastasis tulang sehingga perlu diberikan terapi adjuvan yang berfungsi mencegah osteolisis (antiresorptive agent) dan potensial sebagai antikanker. Hasil uji praklinik dan uji klinik menunjukkan bahwa asam zoledronat yang diberikan bersama sama dengan terapi endokrin mempunyai kemampuan sebagai antiresorptive agent dan potensial sebagai antikanker. Potensi anti kanker asam zoledronat ditunjukkan melalui aktivitas penghambatan perkembangan metastasis tulang dengan cara membuat lingkungan di tulang tidak kondusif terhadap pertumbuhan dan proliferasi sel kanker ${ }^{4,6}$.

\section{KESIMPULAN}

Dari 30 pasien premenopausal EBC dengan hormon responsif dan Her-2 negatif yang telah mendapatkan tindakan pembedahan pada tahun 2010-2013, diketahui bahwa semua pasien mendapatkan terapi adjuvan kemoterapi menggunakan regimen kombinasi dan semua pasien mendapatkan terapi endokrin berupa tamoxifen. Relaps terjadi pada 11 pasien $(36,67 \%)$ dan kejadian relaps paling banyak adalah metastasis tulang yaitu pada 8 pasien $(26,67 \%)$.

\section{DAFTAR PUSTAKA}

1. Brewster AM, Hortobagyi GN, Broglio KR, et al. Residual Risk of Breast Cancer Recurrence 5 Years After Adjuvant Therapy. J Natl Cancer Inst. 2008;100(16):1179-1183. doi:10.1093/jnci/djn233.

2. Burstein HJ, Temin S, Anderson H, et al. Adjuvant endocrine therapy for women with hormone receptor-positive breast cancer: american society of clinical oncology clinical practice guideline focused update. $J$ Clin Oncol. 2014;32(21):2255-2269.

doi:10.1200/JCO.2013.54.2258.

3. Crown J, O'Leary M, Ooi W-S. Docetaxel and paclitaxel in the treatment of breast cancer: a review of clinical experience. Oncologist. 2004;9 Suppl 2(suppl 2):24-32. doi: 10.1634/theoncologist.9-suppl_2-24.

4. Gnant M. Zoledronic acid in breast cancer: latest findings and interpretations. Ther Adv Med Oncol. 
2011;

3:293-301.

doi:10.1177/1758834011420599.

5. Gnant M, Mlineritsch B, Schippinger W, et al. Endocrine therapy plus zoledronic acid in premenopausal breast cancer. $N$ Engl J Med. 2009;360(7):679-691. doi:10.1056/NEJMoa0806285.

6. Hadji P, Frank M, Jakob A, Siebers JW. Effect of adjuvant bisphosphonates on disease-free survival in early breast cancer: Retrospective analysis results in an unselected single-center cohort. J Bone Oncol. 2013;2(1):2-10. doi: 10.1016/j.jbo.2013.01.001.

7. Payne SJL, Bowen RL, Jones JL, Wells CA. Predictive markers in breast cancer The present. Histopathology. 2008;52(1):82-90. doi:10.1111/j.13652559.2007.02897. x.

8. Newman L, Kuerer $H$, Hunt $K$, et al. Local recurrence and survival among black women with early-stage breast cancer treated with breast-conservation therapy or mastectomy. Ann Surg Oncol. 1999;6(3):241-248. doi:10.1007/s10434999-0241-y.

9. Irwan, Azamris, Bachtiar H. Perbandingan Prognosis Subtipe Molekuler Kanker Payudara Antara Pasien Kanker Payudara. MKA. 2015;38(3):208-217. http://jurnalmka.fk.unand.ac.id.

10. Rianti, Emy. Tirtawati, Gusti Ayu. Novita H. Faktor-Faktor yang
Berhubungan dengan Kanker Payudara Wanita. J Heal Qual. 2012;3(1):10-23.

11. Senkus E, Kyriakides S, Ohno S, et al. Primary breast cancer: ESMO Clinical Practice Guidelines for diagnosis, treatment and follow-up. Ann Oncol. 2015;26: v8-v30. doi:10.1093/annonc/mdv298.

12. Kementerian Kesehatan Republik Indonesia. Infodatin: Pusat Data Dan Informasi Kementerian Kesehatan RI.; 2015.

13. Kementerian Kesehatan Republik Indonesia. Panduan Nasional Penanganan Kanker: Kanker Payudara.; 2015.

14. Kurniawan, A; Prayogo N. Tata Laksana Kanker Payudara Relaps. Indones J Cancer. 2012;7(2):87-92.

15. Price, Sylvia A. Wilson LM. Pathophysiology: Clinical Concepts of Disease Processes (Translated by Brahm U.). Jakarta: EGC; 2012.

16. Rasjidi I. Deteksi Dini E Pencegahan Kanker Pada Wanita. Sagung Seto; 2009.

17. Suyatno., Pasaribu ET. Bedah Onkologi Diagnosis Dan Terapi. 2nd ed. Sagung Seto; 2017.

18. Wulandari, R., Prihharsanti, C.H.N., Prajoko YW. Peran Radioterapi Eksterna Adjuvan Terhadap Penderita Kanker Payudara Stadium Lokal-Lanjut: Studi Terhadap Angka Harapan Hidup Dua Tahun. 2012. 